Florida State University College of Law

Scholarship Repository

Scholarly Publications

Spring 2017

\title{
Agency Motivations in Exercising Discretion
}

David L. Markell

Florida State University College of Law

Follow this and additional works at: https://ir.law.fsu.edu/articles

Part of the Administrative Law Commons, and the Entertainment, Arts, and Sports Law Commons

\section{Recommended Citation}

David L. Markell, Agency Motivations in Exercising Discretion, 32 J. LAND USE \& ENVTL. L. 513 (2017), Available at: https://ir.law.fsu.edu/articles/604

This Article is brought to you for free and open access by Scholarship Repository. It has been accepted for inclusion in Scholarly Publications by an authorized administrator of Scholarship Repository. For more information, please contact efarrell@law.fsu.edu. 


\title{
AGENCY MOTIVATIONS IN EXERCISING DISCRETION
}

\author{
DAVID L. MARKELL*
}

The search for the optimal structure of the administrative state in the United States has been ongoing for decades and shows no sign of abating anytime soon. ${ }^{1}$ It has spawned a rich debate about the proper roles of key federal government actors including the judicial, ${ }^{2}$ legislative, ${ }^{3}$ and executive branches. ${ }^{4}$ Consideration of the appropriate roles for administrative agencies, sometimes referred to as the

* Steven M. Goldstein Professor and Associate Dean for Research, The Florida State University College of Law. Blair Schneider (FSU '18) and Samuel Walenz (FSU '18) provided very helpful research assistance.

1. See, e.g., Richard A. Epstein, A Revolution in Administrative Law, HoOvER INSTITUTION DEFINING IDEAS (Jan. 16, 2017) (suggesting that Congress is considering legislation that "could fundamentally alter" the structure of American administrative law for years to come."); Samuel Estreicher \& Steven Menashi, Taking Steel Seizure Seriously: The Iran Nuclear Agreement and the Separation of Powers, 86 FORDHAM L. REV. (forthcoming 2017), https://ssrn.com/abstract-2903574 (providing one example of the ongoing character of this debate, arguing that former President Obama's actions in the 2015 agreement with Iran violate separation-of-powers limits on executive power). For an overview of the "adminstrative state," see, e.g., JoHN F. MANNING \& MATTHEW C. STEPHENSON, LEGISLATION AND REGULATION 332 (2d ed. 2013). For an exploration of the concept of "optimal governance" in the environmental arena, see, e.g., Daniel C. Esty, Toward Optimal Environmental Governance, 74 N.Y.U. L. REV. 1495 (1999).

2. See Richard J. Pierce, JR., Sidney A. Shapiro \& PaUl R. VerkUIL, AdministraTIVE LAW AND PROCESS 126-133 (5 th $^{\text {ed. }}$ 2009) (discussing the role of judicial review); Emily Hammond \& David Markell, Administrative Proxies for Judicial Review: Building Legitimacy from the Inside-Out, 37 HARV. ENVTL. L. REV. 313, 314-315 (2013) (collecting some of the literature that considers judicial review and noting that judicial review is considered a "critical legitimizer of the administrative state," making the lack of such review of many agency decisions one of the "great paradoxes" in administrative law).

3. Congress's roles include serving as a gatekeeper for agency action (e.g., discussed in nondelegation cases such as Whitman v. Am. Trucking Ass'ns, 531 U.S. 457 (2001)) and providing oversight through a variety of mechanisms. ALISSA M. DOLAN ET AL., CONGRESSIONAL RESEARCH SERVICE, CONGRESSIONAL OVERSIGHT MANUAL (Dec. 19, 2014) (discussing Congressional oversight tools); MAEve P. CAREY ET AL., CONGRESSIONAL RESEARCH SERVICE, THE CONGRESSIONAL REVIEW ACT: FREQUENTLY ASKED QUESTIONS (Nov. 17, 2016). Views about Congressional power have ebbed and flowed. See, e.g., THE FEDERALIST NO. 48, at 309 (discussing the concern that the legislative branch may have too much power); Jennifer Nou, Subdelegating Powers, 116 CoLUM. L. REV. 15 (forthcoming 2017) (manuscript at 35) [hereinafter Nou, Subdelegating Powers] (suggesting that Congress's role has diminished in recent years).

4. See Elena Kagan, Presidential Administration, 114 HARV. L. REV. 2245, 2341 (2001) (highlighting the importance of the President's role, including the President's "ability to effect comprehensive, coherent change in administrative policymaking"); Eric A. Posner \& Adrian Vermeule, Crisis Governance in the Administrative State: $9 / 11$ and the Financial Meltdown of 2008, 76 U. CHI. L. REV. 1613, 1614 (2009) (suggesting that "[i]n the modern administrative state, it is practically inevitable that legislators, judges, and the public will entrust the executive branch with sweeping power to manage serious crises. . .."). For an overview of presidential efforts to influence agencies through the Office of Management and Budget's (OMB) Office of Information and Regulatory Affairs (OIRA) and directives to agencies, see JoHN F. MANNING \& MATTHEW C. STEPHENSON, LEGISLATION AND REGULATION 513-539 (2d ed. 2013). For concerns about excessive executive power, see, e.g., BRUCE ACKERMAN, THE DECLINE AND FALL OF THE AMERICAN REPUBLIC 4 (2010). 
fourth branch of government, has been one of the important strands in this debate. ${ }^{5}$ The enormous reach and impact of the administrative state no doubt contributes to the extraordinary amount of attention to and interest in how our government operates. ${ }^{6}$

One issue that continues to attract significant attention concerns how much discretion agencies should enjoy in the operation of the administrative state. As Professors Cary Coglianese and Christopher Yoo note, "[w]hat actions these domestic agencies take and how they make their decisions matter greatly, making the discretion exercised by these administrative institutions a proper matter for both investigation and concern."7 Professors John Manning and Matthew Stephenson suggest that the legal regimes that govern the operation of the administrative state have as an important focal point the tension between empowering bureaucrats, and simultaneously limiting their discretion:

Debate about the appropriate shape and content of the administrative state obviously has extended well beyond these actors to include state and local (and other) governments, and non-governmental organizations. Extensive literatures consider these actors. See, e.g., David E. Adelman \& Kirsten H. Engel, Adaptive Federalism: the Case Against Reallocating Environmental Regulatory Authority, 92 MINN. L. REV. 1796 (2008) (discussing federalism issues in light of climate change challenges); Nestor M. Davidson, Cooperative Localism: Federal-Local Collaboration in an Era of State Sovereignty, 93 VA. L. REV. 959, 960 (2007) (discussing the concept of "cooperative localism"); David L. Markell, Emerging Legal and Institutional Responses to Sea-Level Rise in Florida and Beyond, 42 COLUM. J. ENVTL. L. 1, 20 (2016) (discussing innovative experiments with regional governance models, and the roles of non-governmental organizations and individuals).

5. For two examples of the voluminous literature considering the role of agencies, see, e.g., Peter L. Strauss, The Place of Agencies in Government: Separation of Powers and the Fourth Branch, 84 CoLUM. L. REV. 573, 578 (1984) (describing agencies as the fourth branch of government); Anne Joseph O'Connell, Political Cycles of Rulemaking: An Empirical Portrait of the Modern Administrative State, 94 VA. L. REV. 889 (2008).

6. City of Arlington v. FCC, 133 S.Ct. 1863, 1878 (2013) (Roberts, C.J., dissenting) (discussing the "vast power" of the administrative state); Cary Coglianese \& Christopher S. Yoo, The Bounds of Executive Discretion in the Regulatory State, 164 U. PA. L. REV. 1587, 1589 (2016) (noting that the "vast apparatus of the regulatory state . . has grown dramatically since the founding of the United States" and "affect[s] almost every important facet of contemporary life").

Separation of powers and other constitutional issues of foundational importance that are associated with the administrative state obviously help to account for the sustained attention that the structure and operation of our federal government has received. See, e.g., Neal Kumar Katyal, Internal Separation of Powers: Checking Today's Most Dangerous Branch from Within, 115 YALE L. J. 2314, 2316, 2317 (2006) (discussing how separation of powers [might] be reflected within the executive branch" and aiming to "fill [a] gap" in thinking regarding "checks on the President. . . . beyond . . . wishful thinking about congressional and judicial activity").

7. Coglianese \& Yoo, supra note 6, at 1589; see also Coglianese \& Yoo, supra note 6, at 1606 (noting that "[w]hat counts as an abuse of executive discretion, and how best to try to prevent those abuses through law, extralegal norms, or politics, will remain among the most pressing questions at the center of constitutional governance in the United States"); Elizabeth Magill, Agency-Self-regulation, 77 GEO. WASH. L. REV. 859, 860 (2009) (noting that "[d]iscretion is at the center of most accounts of bureaucracy") 
[M] uch of what we call 'administrative law' can be thought of as a response to [concerns about excessive concentration of power in unelected bureaucrats]. .. The central problem or tension that runs throughout much of our administrative law is how to reap the perceived benefits of broad delegations-flexible, expert decision-making insulated from the distorting influence of day-to-day partisan politics-while avoiding the perceived danger of arbitrary, abusive government by unelected and unaccountable bureaucrats. ${ }^{8}$

The Florida State University College of Law 2016 Environmental Law Without Courts Symposium focused on a question of foundational importance that relates directly to agencies' exercise of discretion, notably why agencies act as they do when they have discretion to pursue different courses of action. The Symposium featured a range of presentations that consider how federal agencies operate when judicial review is unlikely or entirely unavailable. ${ }^{9}$ The current salience of these issues highlights the ongoing debate about the appropriate roles of different actors in the operation of the" administrative state. ${ }^{10}$

One paper, Agency Behavior and Discretion on Remand, ${ }^{11}$ coauthored by leading administrative law scholars Robert Glicksman and Emily Hammond, considers how agencies exercise their discretion when a court invalidates an agency action. Recognizing that an agency's subsequent action will likely be subject to judicial review, Glicksman and Hammond focus on the "in-between" stage: "agency behavior following remand."12 Concluding that "[an] agency's

8. MANNING \& STEPHENSON, supra note 4, at 542; see also Gutierrez-Brizuela v. Lynch, 834 F.3d 1142, 1149 (10th Cir. 2016) (Gorsuch, J., concurring) (noting that "Chevron and Brand $X$ permit executive bureaucracies to swallow huge amounts of core judicial and legislative power and concentrate federal power in a way that seems more than a little difficult to square with the Constitution of the framers' design. Maybe the time has come to face the behemoth.").

9. Papers developed for the Symposium include: Eric Biber, Looking Toward the Future of Judicial Review for Public Lands, 32 J. LAND USE \& ENVTL. L. 359 (2017); Robin Kundis Craig \& Catherine Danley, Federal Fisheries Management: A Quantitative Assessment of Federal Fisheries Litigation Since 1976, 32 J. LAND USE \& ENVTL. L. 381 (2017); Sarah E. Light, The Military-Environmental Complex and the Courts, 32 J. LAND USE \& ENVTL. L. 455 (2017); Robert Glicksman \& Emily Hammond, Agency Behavior and Discretion on Remand, 32 J. LAND USE \& ENVTL. L. 483 (2017); Emily Bremer \& Sharon Jacobs, Agency Innovation in Vermont Yankee's White Space, 32 J. LAND USE \& ENVTL. L. 523 (2017).

10. See supra note 1. The ongoing debate about the Regulations from the Executive in Need of Scrutiny (REINS) Act is one example of the current salience of these issues. S. 21, 115th Cong. (2017).

11. Glicksman \& Hammond, supra note 9 .

12. Id. at 484 . 
response on remand is often left open to the agency's discretion,"13 Glicksman and Hammond hypothesize that at least four factors are likely to influence how agencies exercise their discretion when they act on remand. ${ }^{14}$

One such factor is the type of remand by the court. ${ }^{15}$ For example, Glicksman and Hammond observe that a remand in which a court imposes mandatory relief that details "the nature of the agency's required response," and retains jurisdiction, would confine agency discretion much more than a remand that does not involve either, such as a remand that vacates a rule in its entirety. ${ }^{16}$

A second variable is the time the agency has to act. ${ }^{17}$ Glicksman and Hammond suggest that a remand that directs an agency to act within a particular time frame is likely to limit agency discretion in a way that a remand that lacks such a timeline for agency action does not. They predict that, for example, "a very long timetable," or no timetable at all, increases the odds that the agency will take no further action on the matter remanded. ${ }^{18}$

A third variable that Professors Glicksman and Hammond hypothesize is likely to affect an agency's exercise of discretion on remand is the valence of the agency action. ${ }^{19}$ Glicksman and Hammond's characterization of valence has several dimensions involving a range of actors, including the agency, the litigants, and the President. For instance, Glicksman and Hammond hypothesize that if the agency and President disagree on the merits with the prevailing litigant, the result is likely to be delay in response or an exercise of discretion that is "contrary to the court's expressed interests."20

Finally, Glicksman and Hammond hypothesize that the timing of the Presidential Administration ${ }^{21}$ may influence agency exercises of discretion. In addition to valence, the identity of the political party in power at the time a rule is finalized and at the time of remand may affect an agency's exercise of discretion. Pointing to the

13. Id. (also noting that "agencies frequently have significant latitude in whether, how, and when (if ever) to remedy the initial flaw"). Glicksman and Hammond also recognize that the nature of the remand may influence the extent of agency discretion; for example, a court's issuing a mandamus may significantly curtail agency latitude: "[w]e suspect that, barring a specific and enforceable judicial directive, agencies have almost as much discretion as they would in the first instance, when deciding whether and how to regulate after a judicial remand." Id. at 486 .

14. Id. at 485-86. Glicksman and Hammond recognize that other variables influence agency decisions as well. See id. at 511.

15. Id. at $489-94$.

16. Id. at $490-92$.

17. Id. at $494-95$.

18. Id. at 495 .

19. Id. at $496-97$.

20. Id. at 496 .

21. Id. at 497-99. 
U.S. Environmental Protection Agency's (EPA) approach in the Michigan v. EPA litigation, ${ }^{22}$ Glicksman and Hammond suggest that an agency may act quickly on remand if there is an upcoming election, as EPA did in that case. ${ }^{23}$

Ultimately, Glicksman and Hammond hope that their article contributes to a richer understanding of the factors that motivate agencies to behave in particular ways. Presumably (and hopefully), improved understanding of agency motivations will lead to improved institutional design of the administrative state.

My purpose in this brief Comment is to suggest four additional variables that might provide insights about the drivers of agency discretionary actions on remand, based in part on the conceptual framework that Professor Glicksman and I advance in Dynamic Governance in Theory and Application, Part $I,{ }^{24}$ and in the case study we provide in Unraveling the Administrative State: Mechanism Choice, Key Actors, and Tools. ${ }^{25}$ Most of these variables relate to the idea, captured in the emerging "inside-out" literature, that close attention to internal agency operations may yield helpful insights concerning agency motivation, and with respect to the optimal institutional design of agencies and of the administrative state more generally. ${ }^{26}$

In Dynamic Governance, Professor Glicksman and I offer a conceptual framework for considering institutional design options

22. $135 \mathrm{~S}$. Ct. 2699 (2015).

23. Glicksman \& Hammond, supra note 9, at 511 n.136

24. David L. Markell \& Robert L. Glicksman, Dynamic Governance in Theory and Application, Part I, 58 ARIZ. L. REV. 563 (2016) [hereinafter Markell \& Glicksman, Dynamic Governance].

25. David L. Markell \& Robert L. Glicksman, Unraveling the Administrative State: Mechanism Choice, Key Actors, and Tools (forthcoming 2017) [hereinafter Markell \& Glicksman, Unraveling the Administrative State]. As is, Tm sure, apparent from the fact that I have co-authored with Professor Hammond and with Professor Glicksman, I hold each scholar in high regard. My comments on their article are an effort to contribute to an ongoing dialogue about opportunities to improve understanding of the operation of the administrative state.

26. The first of the four variables I discuss as influencing agency discretionary actionskey features of the statutory scheme as an important source of context-is not one we discuss directly in these articles. The other three variables I discuss relate directly to the articles. Id. This effort to identify additional variables that may be salient in understanding agency responses on remand is not intended to exhaust the variables that may be of value for this purpose. For discussion of the "inside-out" literature, see, e.g., Sidney A. Shapiro \& Ronald F. Wright, The Future of the Administrative Presidency: Turning Administrative Law Inside Out, 65 U. Miami L. Rev. 577 (2011); Emily Hammond \& David L. Markell, Administrative Proxies for Judicial Review: Building Legitimacy From the Inside Out, 37 HARV. ENVTL L. REV. 313 (2013) (discussing the inside-out literature). Glicksman and Hammond recognize that "internal" means of decisionmaking, including an agency's structure, may influence the agency's exercise of discretion. Glicksman \& Hammond, supra note 9, at 511. Other actors play key roles as well. See Jody Freeman \& Jim Rossi, Agency Coordination in Shared Regulatory Space, 125 HARV. L. REV. 1131, 1138 (2012) (discussing the effects of overlapping delegations of authority among multiple agencies); Nou, Subdelegating Powers, supra note 3 (discussing the effects of decisionmaking by lower level officials within agencies). 
for the administrative state. We suggest that it is especially important to consider three distinct but related variables. The first involves identifying key actors who are or should be involved in policy formulation, implementation, and review. ${ }^{27}$ The second involves considering legal and other mechanisms available to those actors to carry out their work. ${ }^{28} \mathrm{~A}$ third leg of the framework involves close attention to the tools or strategies that are likely to be helpful in achieving policy objectives. ${ }^{29}$

We situate our framework in a case study of an EPA initiative to improve compliance with the environmental laws known as Next Generation Compliance (Next Gen). ${ }^{30}$ Through this initiative, EPA is using a variety of legal mechanisms (rulemaking, enforcement settlements, and permitting) to expand use of advanced compliance monitoring, transparency, electronic reporting, and other compliance promotion tools. The agency's assumption is that increased use of these tools will lead to better compliance performance, and perhaps produce other benefits as well. ${ }^{31}$ In the articles, we examine the roles of different actors in developing and implementing EPA's strategies, the use EPA has made of different mechanisms in pursuing its objectives, and the extent to which EPA has succeeded in advancing use of different compliance promotion tools. Our effort to review what EPA is undertaking and accomplishing includes a search to understand better the motivations for the agency's behavior.

One variable that may be salient in predicting how agencies exercise discretion on remand involves key features of the statutory scheme involved. Statutory schemes differ along a number of dimensions. To provide a few examples, they differ in the degree of discretion they provide the agency, ${ }^{32}$ in the impacts they are likely to have on the targets of regulation or on the beneficiaries of such

27. Markell \& Glicksman, Dynamic Governance, supra note 24, at 566.

28. Id. Agencies often have considerable discretion in deciding which legal mechanism to use. See, e.g., Heckler v. Campbell, 461 U.S. 458, 467 (1983) (noting that “where an agency's enabling statute expressly requires it to hold a hearing, the agency may rely on its rulemaking authority to determine issues that do not require case-by-case consideration"); NLRB v. Bell Aerospace Co., 416 U.S. 267, 292-93 (1974) (noting that “any rigid requirement to require rulemaking] . . . would make the administrative process inflexible and incapable of dealing with many of the specialized problems which arise."); M. Elizabath Magill, Agency Choice of Policymaking Forum, 71 U. CHIC. L. REV. 1383, 1385 (2004) (describing judicial reaction to agency mechanism choice as "hands-off," "at least at first blush").

29. Markell \& Glicksman, Dynamic Governance, supra note 24, at 566.

30. Id. at $618-29$.

31. Id. at $608-17$.

32. Some delegations of authority are extraordinarily broad, while others are much more narrow. See, e.g., Whitman v. Am. Trucking Ass'ns, 531 U.S. 457, 473 (2001) (upholding a broad Congressional grant of authority to EPA to establish standards "requisite to protect public health from the adverse effects of [pollutants] in the ambient air"). 
regulation, ${ }^{33}$ in their effects on indirect beneficiaries, ${ }^{34}$ and in their implementability. Each of these variables in the content of a statute may influence an agency's actions in a remand context, independent of the nature of the remand itself, timing considerations provided by the court, or the administration involved. Some of these variables may affect "valence," the third variable Glicksman and Hammond identify. ${ }^{35}$ Our study of EPA's efforts to use its legal mechanisms to advance deployment of different agency-preferred compliance promotion tools found significant differences in EPA's deployment of such tools, depending on the statute involved. For example, EPA's use of different mechanisms (e.g., rulemaking versus adjudication) to advance Next Gen tools varies depending on the statute involved. ${ }^{36}$ Such findings suggest that, at a minimum, it would be a worthwhile project to consider the impacts of statutory features on how agencies exercise discretion on remand and more generally.

A second variable that may provide insights about agency motivations on remand involves close attention to how the distribution of power within an agency may affect the agency's response. Agencies have long been considered to be black boxes, with limited effort made to understand the nature and salience of internal distributions of power. ${ }^{37}$ The reality is that distribution of authority and capacity within an agency has important implications for how an agency acts. ${ }^{38}$ The remand context is likely no exception. For example, the distribution of power and capacity between policy staff that is engaged in a particular rulemaking, and agency lawyers, the executive office, and other actors, may affect whose perspectives prevail in formulating an agency response on remand. Efforts to understand agency discretionary actions are likely to be informed by a sophisticated understanding of this dimension

33. Some may put significant numbers of regulated parties out of business, while others may have much less significant impacts. See, e.g., Ass'n of Pac. Fisheries v. EPA, 615 F.2d 794, 808 (9th Cir. 1980) (noting that an EPA regulation was likely to result in the closure of numerous members of the relevant regulated party community).

34. Some may have very significant impacts on indirect beneficiaries, while others are likely to have far less significant effects. See, e.g., Todd J. Zywicki, Environmental Externalities and Political Externalities: The Political Economy of Environmental Regulation and Reform, 73 TUL. L. REV. 845, 879-82 (1999) (identifying the various impacts of commandand-control environmental regulations on industry and environmental interest groups).

35. For example, the nature of impacts and implementability may affect valence.

36. Markell \& Glicksman, Unraveling the Administrative State, supra note 25.

37. Id.; see supra note 1; Elizabeth Magill \& Adrian Vermeule, Allocating Power Within Agencies, 120 YALE L.J. 1032, 1035 (2011); Christopher J. Walker, Inside Agency Statutory Interpretation, 67 STAN. L. REV. 999, 1003 (2015).

38. Christopher J. Walker, Lawmaking Within Federal Agencies and Without Judicial Review, 32 J. LAND USE \& ENVTL. L. 551 (2017); Jennifer Nou, Intra-Agency Coordination, 129 HARV. L. REV. 421, 490 (2015) [hereinafter Nou, Intra-Agency Coordination]; Magill \& Vermeule, supra note 37 , at $1076-83$. 
of agency decisionmaking. Improved understanding of internal distributions of power and capacity has the potential to yield helpful insights concerning why an agency exercised discretion as it did in connection with a particular remand. ${ }^{39}$

A third variable that has potential to offer insights concerning an agency's motivations in responding to a remand involves attention to the agency's choices among mechanisms to implement its desired policy. Agencies typically have a variety of formal and informal mechanisms available to them to carry out their statutory responsibilities. The nature of the agency's mechanism choice may influence its exercise of discretion in the remand context, among others. For example, an agency that considers a rule to be far more effective than an enforcement proceeding as a mechanism to advance its policy objectives would seem much more likely to respond to remand of a rule by re-promulgating than an agency that determines that use of another mechanism besides rulemaking would be productive. An agency's response to a remand, in other words, may depend on the mechanism choices available to it, and its view of the attractiveness of those choices.

The agencies' options, following the remand in Rapanos $v$. United States of a rule that EPA and the U.S. Army Corps of Engineers had adopted to define the concept of "waters of the United States" under the Clean Water Act, ${ }^{40}$ are illustrative. The Court declined to direct the agencies to use a specific procedural mechanism to address the substantive flaws the Court found in the rule. ${ }^{41}$ As a result, as Glicksman and Hammond point out, EPA and the U.S. Army Corps of Engineers had several mechanisms to choose from to provide such a definition. The agencies could use nonbinding guidance, the path the Bush Administration took; ${ }^{42}$ they

39. Issues relating to distribution of power may extend beyond a single agency. For example, agency efforts that are undertaken with the U.S. Department of Justice (DOJ) are influenced by DOJ perspectives as well. See Markell \& Glicksman, Unraveling the Administrative State, supra note 25.

40. 547 U.S. 715,722 (2006).

41. The Court of Appeals remanded "to the district court with instructions to remand to the Army Corps of Engineers for further proceedings consistent with the Supreme Court's decision in Rapanos." Carabell v. U.S. Army Corps of Eng'rs, 217 F. App'x 431, 431 (6th Cir. 2007). Glicksman and Hammond note that the decisions in Rapanos "suggested that rulemaking would be a preferable means of exercising agency discretion. But the decision did not mandate that procedural vehicle." Glicksman \& Hammond, supra note 9, at 502.

42. U.S. Envtl. Prot. AGENCY \& U.S. ARMy CORPS OF Eng'rs, Clean Water ACT JURISDICTION FOLLOWING THE U.S. SUPREME COURT'S DECISION IN RAPANOS $V$. UNITED STATES \& CARABELL V. UNITED STATES (2008), https://www.epa.gov/sites/production/files/ 2016-02/documents/cwa_jurisdiction_following_rapanos120208.pdf. The guidance provided:

The CWA provisions and regulations described in this document contain legally binding requirements. This guidance does not substitute for those provisions or regulations, nor is it a regulation itself. It does not impose legally binding requirements on EPA, the Corps, or the regulated community, and may not apply to a particular 
could use rulemaking, as the Obama Administration did;43 or they could use adjudication, or some combination of these approaches. ${ }^{44} \mathrm{My}$ hypothesis is that consideration of an agency's perception of the benefits and disadvantages of each of the procedural options available to it may advance understanding of why an agency exercises its discretion in a particular way in a specific context, including on remand. Empirical work that incorporates sophisticated treatment of the range of legal mechanisms available to an agency to respond on remand might helpfully contribute to the literature on mechanism choice generally, ${ }^{45}$ and to improved understanding of how agencies are likely to respond in different remand contexts. ${ }^{46}$

A fourth variable that may influence agency decisionmaking on remand involves the particular strategies or tools an agency is interested in advancing. For example, in its Next Gen initiative EPA identified several tools that it believes will promote improved compliance. ${ }^{47} \mathrm{On}$ remand of a rule that proposes to incorporate one or more of such tools, EPA may well consider the range of tools it is seeking to use, and the relative value of each such tool in connection with the particular rule involved. Thus, EPA's response to a remand may depend on the agency's assessment of the costs and benefits of employing one or more of the range of tools the agency is interested in deploying. In short, my hypothesis is that the particular mix of substantive goals an agency is seeking to advance may influence its

situation depending on the circumstances. Any decisions regarding a particular water will be based on the applicable statutes, regulations, and case law.

Id. at 4 n. 17 .

43. See Definition of "Waters of the United States" Under the Clean Water Act, 79 Fed. Reg. 22, 188 (Apr. 21, 2014) (codified at 33 C.F.R. $\$ 328$ (2017) (notice of proposed rulemaking); Clean Water Act Rule: Definition of "Waters of the United States," 80 Fed. Reg. 37,054 (June 29, 2015) (codified at 33 C.F.R. $§ 328$ (2017) (final regulations). On October 9, 2015, the U.S. Court of Appeals for the 6th Circuit stayed the Waters of the United States rule. In re E.P.A., 803 F.3d 804, 808-09 (6th Cir. 2015). On February 28, 2017, President Trump signed Exec. Order No. 13,778, 82 Fed. Reg. 41 (March 3, 2017), which directs EPA to review the Waters of the United States Rule.

44. Glicksman \& Hammond, supra note 9, at 501-03.

45. For examples of this literature, see, e.g., Emily Hammond Meazell, Deference and Dialogue in Administrative Law, 111 CoLuM. L. REv. 1722, 1739 (2011); Peter Schuck \& E. Donald Elliot, To the Chevron Station: An Empirical Study of Federal Administrative Law, 1990 DUKE L.J. 984; Wendy Wagner, Revisiting the Impact of Judicial Review on Agency Rulemakings: An Empirical Investigation, 53 WM. \& MARY L. REV. 1717 (2012).

46. For an effort to explore agency mechanism choice in this way, see Markell \& Glicksman, Unraveling the Administrative State, supra note 25.

47. See Cynthia Giles, Next Generation Compliance, ENVTL. F. 22 (Sept.-Oct. 2013); see also David A. Hindin \& Jon D. Silberman, Designing More Effective Rules and Permits, 7 GEo. WASH. J. ENERGY \& ENVTL. L. 103 (2016); David L. Markell \& Robert L. Glicksman, Next Generation Compliance, 30 NAT. RESOURCES \& ENV'T 22 (2016). 
response on remand. ${ }^{48} \mathrm{As}$ a result, close attention to such goals may also produce helpful insights concerning how agencies are likely to respond on remand.

In conclusion, one of the important challenges for the extensive literatures that grapple with the structure and operation of the administrative state is to improve understanding of why agencies act as they do when, as is often the case, they enjoy considerable autonomy or discretion. The aim of the 2016 Florida State University College of Law Environmental Law Without Courts Symposium, and the articles comprising this issue of the Journal of Land Use and Environmental Law, including the helpful contribution by Professors Glicksman and Hammond and this Comment, is to contribute to the effort to build an improved understanding of this foundational feature of the administrative state. 